\title{
Characterization of tuna (Thunnus albacares) skin gelatin edible film incorporated with clove and ginger essential oils and different surfactants
}

\author{
${ }^{1}$ Sutrisno, E., ${ }^{1, *}$ Ningrum, A., ${ }^{1}$ Supriyadi, ${ }^{2}$ Munawaroh, H.S.H., ${ }^{2}$ Siti Aisyah and \\ ${ }^{3}$ Susanto, E. \\ ${ }^{1}$ Department of Food Science and Technology and Agricultural Product Technology, Faculty of \\ Agricultural Technology, Gadjah Mada University, Jl. Flora No 1, Bulaksumur Yogyakarta 55281, \\ Yogyakarta, Indonesia \\ ${ }^{2}$ Chemistry Program, Department of Chemistry Education, Faculty of Mathematics and Science Education, \\ Universitas Pendidikan Indonesia, Bandung 40154, West Java, Indonesia \\ ${ }^{3}$ Department of Fisheries Products Technology, Faculty of Fisheries and Marine Science, Diponegoro \\ University, Jl. Prof. Soedarto SH Kampus Tembalang, Semarang 50275, Republic of Indonesia
}

\section{Article history:}

Received: 18 June 2020

Received in revised form: 22 July 2020

Accepted: 16 August 2020

Available Online: 8

November 2020

Keywords:

Edible film,

Gelatin,

Tuna skin,

Essential oils,

Surfactants

DOI:

https://doi.org/10.26656/fr.2017.5(2).285

\begin{abstract}
Tuna skin gelatin has the ability to form a good film, transparent color, and a good barrier against oxygen, $\mathrm{CO}_{2}$, and lipids. But the tuna skin gelatin edible film needs to be modified by adding hydrophobic materials and surfactants, to improve their physical and functional properties. The objectives were to determine the physical properties, antioxidant activity, and antimicrobial of tuna skin gelatin edible film were incorporated with ginger, clove essential oils, and surfactants. The stage 1) the extraction of gelatin from the tuna fish skin, 2) making edible films: ginger-tween edible film (GTF), ginger-soy lecithin edible film(GSF), clove-Tween ${ }^{\circledR} 20$ edible films (CTF), and clove-soy lecithin edible film (CSF). The results showed an increase of thickness, ${ }^{*} b$ values, and the highest value $(* b)$ on GTF, but did not significantly affect ${ }^{*} L$ and $* a$ value. CTF and CSF have higher tensile strength compared to GTF, GSF, and control but not significantly different for elongation at break for all samples. Water vapor permeability was not significantly different amongst all edible films. Solubility decrease when clove essential oil was incorporated, in comparison with GTF, GSF, and control. Fourier transform infrared spectroscopy analyses spectra indicated that edible film added with clove essential oil and soy lecithin exhibited higher hydrophobicity than the control edible film. CTF showed the highest DPPH radical scavenging activities and the highest antimicrobial inhibitory activity. Therefore, clove essential oil and both surfactants could affect the physical and functional properties of resulting edible films.
\end{abstract}

\section{Introduction}

In the fisheries industry, fish filet processing produces large amounts (more than 75\%) of by-products that are not edible, which are thrown away as waste or are underused in some parts of the world. The byproducts of processing marine products are rich in useful sources of biomolecules such as collagen and gelatin (Newton et al., 2014). One type of fish whose byproducts have not been widely used is tuna skin. The Indonesian Ministry of Fisheries and Maritime Affairs in 2018 reported that tuna production in Indonesia amounted to 409,024.18 tons (Anonim, 2020). This large amount of production is also followed by large byproducts that are not used or thrown away.
Gelatin from fish can be an alternative film material. Gelatin has been widely used as a starting material for film formation. Among biopolymers, proteins have the good film-forming ability, transparent color, and oxygen, $\mathrm{CO}_{2}$, and lipid barrier properties (Lacroix and $\mathrm{Vu}, 2014$ ). However, films derived from pure gelatin also show weaknesses that have low water vapor barrier properties (Hoque et al., 2011).

The physical and functional properties of food product packaging are very important to maintain or increase the shelf life of a food product. Therefore we need food product packaging that has good physical and functional properties such as containing antioxidants, antimicrobials, and biodegradable properties (Gómez- 
Guillén et al., 2009).

The characteristics of a good edible film can be achieved by improving the process and adding ingredients that can improve physical and functional properties such as antioxidants and antimicrobials. Hydrophobic materials such as fat, wax, and fatty acids can be added to the film from fish gelatin to improve physical, mechanical properties including water resistance and water vapor barrier (Nor Amalini et al., 2018). Essential oil is a hydrophobic material that is thought to improve physical, mechanical properties including water resistance and water vapor barrier from films incorporated into films from protein material.

It is hoped that the incorporation of essential oils will not only improve physical properties The incorporation of essential oils not only improves physical properties but also increases the antioxidant and antimicrobial activity of the edible film produced. As a result, the film can function as an active packaging material for food protection and preservation. One of the wealth of spices in Indonesia is the clove. So far, clove is more widely used in cigarette production, and less is used in food, especially essential oils. The main component of clove essential oil is eugenol $(56.06 \%)$ followed by caryophyllene $(39.63 \%)$ and $\alpha$-caryophyllene (4.31\%), where this component has natural antioxidant potential based on the DPPH test (Radünz et al., 2019). While one type of herbs that are widely used in food is ginger. The main component of ginger essential oil is camphene, sabinene, $\alpha$-curcumin, zingiberene, $\alpha$-farnesene, $\beta$ sesquiphellandrene, neral, and geranial, where the active component is effective in counteracting free radicals and can be used as a natural antioxidant (Yeh et al., 2014). Besides having potential as an antioxidant, essential oils both clove and ginger also have the potential as an antibacterial. The antibacterial activity of essential oils is caused by essential oils containing compounds that can kill or inhibit bacterial growth. The content of antibacterial compounds in clove flowers are flavonoids, tannins, alkaloids, and eugenol (Rukmana dan Yudirachman, 2016). While ginger essential oil with the main content of zingiberene showed significant antibacterial activity against Bacillus subtilis, Staphylococcus aureus, Escherichia coli, Pseudomonas aeruginosa, Candida albicans, and Aspergillus niger (Sharma et al., 2016).

In addition to essential oils to produce good edible film characteristics (emulsion films), effective surfactants are needed to stabilize the emulsion during the preparation of film-forming solutions and film casting (Hsu and Nacu, 2003). Some common types of surfactants added in film making are Tween ${ }^{\circledR} 20$ and soy lecithin. The difference in surfactant addition will affect the structure or morphology and characteristics of edible films (Tongnuanchan et al., 2014). Several previous studies related to efforts to improve the physicalmechanical and functional properties of edible films from fish gelatin, (Tongnuanchan et al., 2012) examining films derived from tilapia skin incorporated with bergamot, kaffir lime, lemon, and lime with the addition of glycerol and surfactants (Tween $\left.{ }^{\circledR} 20\right)$, films from the tilapia skin incorporated in volatile basil (Ocimum basilicum), plai (Zingiber montanum) and lemon (Citrus limonum) as well as with the addition of glycerol and surfactants (soy lecithin) (Tongnuanchan et al., 2014) and added edible film of silver carp fish with cinnamon, glycerol, and Tween ${ }^{\circledR} 80$ essential oils (Wu et al., 2017). However, little information regarding the effect of the addition of cloves, ginger essential oils, and different surfactants (soy lecithin, Tween ${ }^{\circledR}$ 20) on physical properties, antioxidant and antibacterial activity of edible films from tuna skin gelatin. The objective of this investigation was to study the effect of adding clove and ginger essential oils and surfactant types (soy lecithin, Tween ${ }^{\circledR} 20$ ) on physical properties, antioxidant activity, and antibacterial edible film of tuna skin gelatin.

\section{Materials and methods}

\subsection{Materials}

The material used in this research is tuna skin from Bantul Special Region of Yogyakarta, Indonesia. Clove and ginger essential oils were obtained from CV. Nusa Aroma Jakarta, Indonesia. The chemicals were glycerol, soy lecithin, Tween ${ }^{\circledR}$ 20, 2,2 - Diphenyl-1-Picryl Hidrazyl (DPPH), methanol, $\mathrm{NaOH}$ (Merck, Jerman), citric acid, sulfuric acid (Merck, Jerman), and aquadest, the culture of Staphylococcus aureus, Escherichia coli, nutrient broth, and nutrient agar media.

\subsection{Extraction of tuna skin gelatin}

First, fresh tuna skin was washed and removed the residual fat. Tuna skin was cut into small pieces $(0.5 \mathrm{x}$ $0.5 \mathrm{~cm}$ ) and then demineralized by immersing in a $0.2 \%$ $\mathrm{NaOH}$ solution for $2 \mathrm{hrs}$ at a ratio of 1:6 (w/v). Then, the tuna skin sample was drained and washed with clean water up to $\mathrm{pH} 7$ and soaked again with $0.2 \% \mathrm{H}_{2} \mathrm{SO}^{4}$ for $2 \mathrm{hrs}$ with a sample ratio with 1: $6(\mathrm{w} / \mathrm{v})$ acid solution. Then the tuna skin sample was washed with water up to pH 7 and finally soaked with $0.1 \%$ citric acid solution for $2 \mathrm{hrs}$ 1:6 (w/v) ratio and then washed again with water up to $\mathrm{pH} 7$. Tuna skin that has been treated with $\mathrm{NaOH}, \mathrm{H}_{2} \mathrm{SO}^{4}$, and citric acid then was extracted using aqua dest with a ratio of $1: 3(\mathrm{w} / \mathrm{v})$ at $60^{\circ} \mathrm{C}$ for $6 \mathrm{hrs}$ and continued with filtration. The drying process was carried out at a temperature of $50{ }^{\circ} \mathrm{C}$ for $36-48 \mathrm{hrs}$ with a cabinet 
dryer to obtain a gelatin sheet. Then the gelatin was milled to obtain gelatin powder (Tkaczewska et al., 2018).

\subsection{Preparation edible films}

Edible film preparation was based on the previous method (Tongnuanchan et al., 2014) with some modifications. To make a film-forming solution or filmforming solution (FFS) of $3 \mathrm{~g}$ of gelatin powder was dissolved in distilled water to obtain a concentration of $3 \%(\mathrm{w} / \mathrm{v})$. The solution was heated at $50^{\circ} \mathrm{C}$ for $30 \mathrm{mins}$. Then, glycerol was added as much as $20 \%(\mathrm{w} / \mathrm{w})$ of gelatin as a plasticizer. Before being added to FFS, essential oils of cloves, ginger $(100 \% \mathrm{v} / \mathrm{w})$ from gelatin were mixed with surfactants (soy lecithin, Tween ${ }^{\circledR} 20$ ) as much as $25 \%$ (w/v of essential oils). Then the solution obtained was homogenized with a homogenizer at 4,200 rpm for 5 mins. The film was then cast in a small plastic tray and dried in a cabinet dryer at a temperature of $50^{\circ} \mathrm{C}$ for 20-24 hrs then the edible film sheet was obtained.

\subsection{Thickness}

Film thickness was measured using a micrometer based on the method of (Tongnuanchan et al., 2013). Five points for each edible film sample were measured for thickness and then averaged as the thickness value of the edible film.

\subsection{Color}

This analysis is used to determine the values of $\mathrm{L}$ (brightness), a (red-green), b (yellow-blue) on edible film. The edible film was placed on a plate reader. Then the reader plate was placed on the chromameter. The edible film was analyzed using chromameter so that the color value will be measured as ${ }^{*} L,{ }^{*} a$, and ${ }^{*} b$ (Nur Hanani et al., 2019).

\subsection{Tensile strength (TS) and elongation at break (EAB)}

Tensile strength (TS) and elongation at break (EAB) were measured using UTM (Universal Testing Machine) Zwick/Z.0.5 Texture Analyzer with slight modification (Pranoto, 2008). Film specimens of size $5 \mathrm{~cm} \mathrm{x} 0.5 \mathrm{~cm}$ were measured in mean thickness using a micrometer. The sample was placed between the grips with an initial distance of $50 \mathrm{~mm}$ and then pulled at a speed of $10 \mathrm{~mm} /$ minute. TS was calculated by dividing the maximum force at breaking with the cross-sectional area of the edible film and was expressed in MPa. Whereas EAB was calculated based on the basis length extended as compared to the original length of the film (read from machine or chart).

\subsection{The solubility of edible film}

The water solubility of the films was based on the method describes elsewhere (Hosseini et al., 2013) with slight modification. Films were cut into $1 \times 4 \mathrm{~cm}^{2}$ size of 3 pieces, then weighed. After that, the sample is dried in an oven at $105^{\circ} \mathrm{C}$ for $24 \mathrm{hrs}$ to determine the initial dry weight (Wi). After that, the film samples were immersed in $30 \mathrm{~mL}$ of distilled water in a tube which is stirred in a water bath at a speed of $100 \mathrm{rpm}$ at room temperature $\left(22-25^{\circ} \mathrm{C}\right)$ for $24 \mathrm{hrs}$. The samples were then passed through a filter paper (Whatman 1). Then the filter paper together insolubilized fraction was dried in an oven $\left(105^{\circ} \mathrm{C}, 24 \mathrm{hrs}\right)$, then the dry sample was weighed (Wf). The percentage of solubility of the sample in water (S) was calculated by the equation:

$$
\mathrm{S}=\frac{\mathrm{W}_{\mathrm{i}}-\mathrm{W}_{\mathrm{f}}}{\mathrm{W}_{\mathrm{i}}} \times 100 \%
$$

\subsection{Water vapor permeability (WVP)}

The water vapor permeability (WVP) of films was measured gravimetrically [Hosseini et al., 2013]. WVP edible film was measured using a bottle made of glass with an inner diameter of $1.3 \mathrm{~cm}$ and $5 \mathrm{~cm}$ height. The edible films without pinholes or any defects were measured thickness by using a micrometer. The vial bottles were filled with $6 \mathrm{~mL}$ of distilled water, and edible films were sealed to the cup mouth, placed in desiccators containing silica gel. The water was transferred through the film and absorbed by the desiccant was determined from the weight loss of the permeation cell. The cells were weighed at intervals of 1 $\mathrm{hr}$ for $7 \mathrm{hrs}$ with an analytical balance. The slope of weight loss versus time was obtained by linear regression. Temperature and storage space were recorded and used to determine the atmospheric partial pressure using a steam table. The value of WVTR (Water Vapor Transfer Rate) was determined by the equation:

$$
\begin{aligned}
& \text { WVTR }=\frac{\Delta \mathrm{w}}{\mathrm{A} \Delta \mathrm{t}} \\
& \mathrm{WVP}=\frac{\mathrm{WVTR} \times \mathrm{L}}{\Delta \mathrm{P}}
\end{aligned}
$$

Where $\Delta \mathrm{w}$ is the weight of water vapor passing through the film (g), L is the thickness of the film (mm), A is the exposed film area and $\Delta \mathrm{P}$ is the partial pressure difference of water vapor $(\mathrm{Pa})$. WVP is expressed in $\mathrm{g} /$ $\mathrm{msPa}$.

\subsection{Fourier transform infrared spectroscopy analyses}

This analysis was carried out to identify the presence of specific chemical groups in a material and to test the efficiency of the crosslinking process. The film needed for this test was $5 \mathrm{mg}$. The film was made in pellets forms then analyzed, this analysis was carried out using 
Fourier Transform Infrared Spectroscopy (FTIR). FTIR spectra were obtained between $4000-500 \mathrm{~cm}^{-1}$ (Sutono and Pranoto, 2013).

\subsection{Antioxidant activity test}

The DPPH radical scavenging activity was based on the method describes elsewhere (Maryam Adilah and Nur Hanani, 2016) with some modifications. $0.1 \mathrm{~g}$ of each film samples were dissolved in $2 \mathrm{~mL}$ methanol. The extract with $10 \mu \mathrm{L}$ was diluted with $990 \mu \mathrm{L}$ methanol (500 ppm). Samples (500 ppm) $100 \mu \mathrm{L}$ were diluted with $900 \mu \mathrm{L}$ methanol then added to $2 \mathrm{~mL}$ of $0.1 \mathrm{mM} \mathrm{DPPH}$ solution in $95 \%$ methanol. Followed by incubation in a dark room for 30 mins and then measured the absorbance at $517 \mathrm{~nm}$ on a spectrophotometer. Antioxidant activity is calculated by the equation:

Radical Scavenging Activity (\%) $=$ Abs DPPH - Abs sample/Abs DPPH x 100\%

\subsection{Antibacterial activities of edible film}

Antibacterial activity of the edible films was tested by the method describes elsewhere (Pranoto et al., 2005) with slight modification. The edible film with a diameter of $10 \mathrm{~mm}$ was placed on the nutrient agar plates, which had been previously seeded $0.1 \mathrm{~mL}$ of a culture of test microorganisms containing $10^{6} \mathrm{CFU} / \mathrm{mL}$. Petri dishes were incubated at $37^{\circ} \mathrm{C}$ for $24 \mathrm{hrs}$. After going through the incubation period, the inhibition zone will appear and measurement of the diameter of the inhibition zone will be measured with the calipers in $\mathrm{mm}$. The diameter of the inhibition zone is calculated as the diameter of the clear zone (including the diameter of the edible film) formed.

\subsection{Statistical analysis}

The measurement results of each variable were analyzed with the SPSS version 25 program. Data were tested statistically using ANOVA. If there were differences between treatments as indicated by the $\mathrm{F}$ count $<\mathrm{F}$ table then the DMRT test was continued at the $5 \%$ significance level to find out the level of further differences.

\section{Results and discussion}

\subsection{Thickness}

The addition of essential oils and surfactants increases the thickness of the edible film. in Table 1 , shows the thickness of edible film added by 2 different types of essential oils and surfactants, having a thickness higher than the edible control film $(\mathrm{P}<0.05)$. This is due to an increase in solid material (solid content) in the edible gelatin film. The essential oil droplet enters and localizes it in the edible film network. As a result, the interaction between gelatin chains could be impeded and then the loss of a compact network of gelatin chains might bring about the protruded structure as indicated by the thickness of the increases. Guided by JIS (Japanese Industrial Standard), plastic films for food packaging that are categorized as films are those that have a maximum thickness of $0.25 \mathrm{~mm}$ (Nurindra et al., 2015). Edible film from tuna skin gelatin (Thunnus albacares) in this study still meets the standard to be categorized as a food packaging film, because the resulting film thickness ranges from $0.113 \pm 0.042$ to $0.184 \pm 0.052 \mathrm{~mm}$. From the results of the thickness value of an edible film, it can be seen that the addition of essential oils and surfactants can increase the thickness value and approach JIS criteria with a value of $0.137 \pm 0.038-0.184 \pm 0.052 \mathrm{~mm}$. Increased film thickness was also reported by (Tongnuanchan et al., 2014) where the thickness of the tuna skin gelatin film incorporated with basil, plai, and lemon essential oil was higher than the control film.

\subsection{Color}

Edible film color is very influential on the appearance of the packaged product. Table 1 presents the color $\left({ }^{*} L, * a\right.$, and $\left.{ }^{*} b\right)$ of edible films incorporated with two types of essential oils and surfactants. Duncan's follow-up test results showed that the addition of essential oils and surfactants had higher ${ }^{*} b$ (yellowness) value $(\mathrm{P}<0.05)$ compared with edible film control, but did not significantly affect ${ }^{*} L$ (lightness) and $* a$ (redness/greenness) value. The highest $* b$ value in the

Table 1. Color of edible film

\begin{tabular}{ccccc}
\hline Sample & Thickness $(\mathrm{mm})$ & $\mathrm{L}^{*}$ & $\mathrm{a}^{*}$ & $\mathrm{~b}^{*}$ \\
\hline Control & $0.113 \pm 0.042^{\mathrm{Aa}}$ & $64.20 \pm 11.24^{\mathrm{Aa}}$ & $1.56 \pm 1.26^{\mathrm{Aa}}$ & $4.58 \pm 1.91^{\mathrm{Aa}}$ \\
GTF & $0.137 \pm 0.038^{\mathrm{Bb}}$ & $65.94 \pm 6.26^{\mathrm{Aa}}$ & $1.10 \pm 1.54^{\mathrm{Aa}}$ & $11.26 \pm 6.13^{\mathrm{Bb}}$ \\
GSF & $0.184 \pm 0.052^{\mathrm{Bb}}$ & $75.30 \pm 5.08^{\mathrm{Aa}}$ & $1.55 \pm 1.40^{\mathrm{Aa}}$ & $22.63 \pm 4.99^{\mathrm{Bb}}$ \\
CTF & $0.181 \pm 0.058^{\mathrm{Bb}}$ & $68.55 \pm 1.75^{\mathrm{Aa}}$ & $1.94 \pm 1.05^{\mathrm{Aa}}$ & $16.80 \pm 5.98^{\mathrm{Bb}}$ \\
CSF & $0.147 \pm 0.058^{\mathrm{Bb}}$ & $69.67 \pm 6.26^{\mathrm{Aa}}$ & $0.64 \pm 0.91^{\mathrm{Aa}}$ & $16.63 \pm 2.42^{\mathrm{Bb}}$ \\
\hline
\end{tabular}

Values with different uppercase letter superscripts indicate significant difference $(\mathrm{p}<0.05)$ among essential oils while values with different lowercase letter superscripts indicate significant difference $(p<0.05)$ in the treatment of surfactants. GTF $=$ gingerTween ${ }^{\circledR} 20$ edible film; GSF = ginger-soy lecithin edible film; CTF = clove-Tween ${ }^{\circledR} 20$ edible film; CSF = clove-soy lecithin edible film. 
edible film added with ginger essential oil and soy lecithin (GSF) is $22.63 \pm 4.99$. The highest $* b$ value is thought to be caused by carotene pigments from soy lecithin (brownish yellow) and curcumin(pale yellow to golden orange) from ginger. ${ }^{*} L$ (lightness) and $*^{*} a$ (redness/greenness) value does not significantly affect with edible film control. This is presumably due to the natural pigment from tuna skin gelatin is light yellow and 2 types of essential oils (ginger, cloves) are yelloworange and brownish-yellow and 2 types of surfactants (Tween ${ }^{\circledR} 20$, soy lecithin) tend to be bright yellow and brownish yellow so does not change the color of the edible film control. According to an earlier study (Tongnuanchan et al., 2014) reported that the tilapia gelatin film which was incorporated with basil, plai, and lemon essential oils and soy lecithin surfactant showed a decrease in ${ }^{*} L$ value, an increase $* a$ value, and an increase in the $* b$ value. The differences in the components of pigments/compounds present in essential oils might determine the difference in the color of the resulting film (Tongnuanchan et al., 2014).

\subsection{Tensile strength (TS) and elongation at break (EAB)}

Tensile strength is the maximum pull that can be achieved until the edible film persists before breaking. Tensile strength is a mechanical property of the edible film. Tensile strength determines the strength of the edible film. The higher the tensile strength, the better edible film can withstand mechanical damage. Table 2 presents the TS and EAB values of edible films incorporated with two types of essential oils and surfactants. Duncan's follow-up test results showed that the value of tensile strength edible film added with soy lecithin was higher $(\mathrm{P}<0.05)$ than edible film added Tween ${ }^{\circledR} 20$, but not significantly different from edible control films $(\mathrm{P}>0.05)$. This can be caused by soy lecithin which has $($ HLB $=4)$ and is included in the low Hydrophile-lipophile balance (HLB) surfactant. The lower the HLB value of a surfactant, it is more hydrophobic (more non-polar groups) (McClements, 2005). Thus the polar group will bind to gelatin while the non-polar group binds to essential oils because the more non-polar group will make the edible film matrix stiff. The addition of clove essential oil significantly affected the TS edible film $(\mathrm{P}<0.05)$, where the clove-soy lecithin edible film (CSF) had the highest tensile strength value. The addition of clove essential oil significantly affected edible film $(\mathrm{P}<0.05)$. This is due to the content of different essential oil components where the main content of clove essential oil is eugenol which is a group of phenolic compounds. The oxidation of phenolic compounds produces quinones, which can react with side chains of protein amino groups via covalent $(\mathrm{C}-\mathrm{N}$ or $\mathrm{C}-$ S) or hydrogen bonding (Makishi et al., 2013). Intermolecular interactions result in cross-links between chains, leading to improved film properties (Choi et al., 2018). This is an agreement with the study earlier (Hoque et al., 2011) reported where essential oils that contain mainly aldehyde, ketone, and phenolic compounds when interacting with protein films will increase the tensile strength of the film.

Elongation at break is the maximum length change experienced by the film until it breaks. The highest elongation value in CTF while the lowest value in GTF. The addition of essential oils and surfactants did not significantly affect the elongation of edible films. The tilapia gelatin film which was incorporated with basil, plai, and lemon essential oils and soy lecithin surfactant showed a decrease in tensile strength and increased EAB (elongation at break) (Tongnuanchan et al., 2014). While the edible film of black tilapia skin added by seaweed extract (Kappaphycus alvarezii) that containing phenol compounds increased tensile strength (TS) and elongation at break properties (Sutono and Pranoto, 2013). But the overall tensile strength and the elongation at break value still conform to the JIS (Japanese Industrial Standard) 1975 which is at least 0.392266 $\mathrm{MPa}$ and at least 70\%, respectively (Nurindra et al., 2015).

\subsection{Water vapor permeability}

WVP (Water Vapor Permeability) is a measure of the ease of water vapor passing through materials, such

Table 2. Tensile Strength (TS), Elongation at Break (EAB), WVP and solubility edible film

\begin{tabular}{ccccc}
\hline Sample & TS $(\mathrm{Mpa})$ & EAB $(\%)$ & WVP $(\mathrm{g} / \mathrm{msPa})$ & Solubility $(\%)$ \\
\hline Control & $1.54 \pm 1.09^{\mathrm{Aab}}$ & $463.74 \pm 28.83^{\mathrm{Aa}}$ & $4.63 \times 10^{-12} \pm 1.49 \times 10^{-12 \mathrm{Aa}}$ & $79.63 \pm 6.29^{\mathrm{Ba}}$ \\
GTF & $0.57 \pm 0.05^{\mathrm{Aa}}$ & $463.16 \pm 50.94^{\mathrm{Aa}}$ & $4.23 \times 10^{-12} \pm 0.93 \times 10^{-12 \mathrm{Aa}}$ & $62.11 \pm 9.19^{\mathrm{ABa}}$ \\
GSF & $1.03 \pm 0.07^{\mathrm{Ab}}$ & $547.17 \pm 11.39^{\mathrm{Aa}}$ & $3.79 \times 10^{-12} \pm 0.66 \times 10^{-12 \mathrm{Aa}}$ & $67.17 \pm 29.97^{\mathrm{ABa}}$ \\
CTF & $1.65 \pm 0.99^{\mathrm{Ba}}$ & $557.52 \pm 10.59^{\mathrm{Aa}}$ & $3.47 \times 10^{-12} \pm 1.02 \times 10^{-12 \mathrm{Aa}}$ & $52.63 \pm 2.58^{\mathrm{Aa}}$ \\
CSF & $3.60 \pm 0.37^{\mathrm{Bb}}$ & $454.41 \pm 55.34^{\mathrm{Aa}}$ & $2.84 \times 10^{-12} \pm 0.76 \times 10^{-12 \mathrm{Aa}}$ & $43.44 \pm 1.93^{\mathrm{Aa}}$ \\
\hline
\end{tabular}

Values with different uppercase letter superscripts indicate significant difference $(p<0.05)$ among essential oils while values with different lowercase letter superscripts indicate significant difference $(p<0.05)$ in the treatment of surfactants. GTF $=$ gingerTween ${ }^{\circledR} 20$ edible film; GSF $=$ ginger-soy lecithin edible film; CTF = clove-Tween ${ }^{\circledR} 20$ edible film; CSF = clove-soy lecithin edible film. 
as biopolymer films. Table 2 presents the WVP values of edible films incorporated with two types of essential oils and surfactants. The value of WVP edible film ranges from $2.84 \times 10^{-12} \pm 8.76 \times 10^{-12} \mathrm{~g} / \mathrm{msPa}$ to $4.63 \times 10^{-12} \pm$ $1.47 \times 10^{-12} \mathrm{~g} / \mathrm{msPa}$. The highest value of WVP was in edible film control, while the lowest was in clove-soy lecithin edible film (CSF). From Duncan's follow-up test results it was found that the addition of essential oils and surfactants did not significantly affect $(\mathrm{P}>0.05)$ on WVP edible film. The addition of essential oils at high concentrations is thought to influence the suboptimal role of essential oil crosslinking, thus causing edible film control not significantly different from the treatment of adding essential oils (3\%). This is an agreement with the study earlier (Nisaa, 2020) reported tilapia skin gelatin film added with $1-2 \%$ cinnamon essential oil was not significantly different from the control film, but at a concentration of $4 \%$ WVP increased (higher than the control film).

Although the WVP value was not significantly different between treatments, there was a decrease in the value of WVP edible control films from $4.63 \times 10^{-12} \pm$ $1.49 \times 10^{-12} \mathrm{~g} / \mathrm{msPa}$ to $2.84 \times 10^{-12} \pm 0.76 \times 10^{-12} \mathrm{~g} / \mathrm{msPa}$ (decreased $38.66 \%$ ) on clove edible films - soy lecithin. The reduction in WVP or the increase in vapor barrier properties in edible gelatin films may be caused by the formation of winding pathways for the spread of steam through the film by reducing the free $-\mathrm{OH} / \mathrm{NH}$ group or increasing the degree of crystallinity of biopolymers (Kanmani and Rhim, 2014). The impact of the lipid addition on the microstructure of the emulsified film is a determining factor in water barrier efficiency (Atares and Chiralt, 2016). The rate of edible film vapor transmission is influenced by several factors, namely the structure of edible films (homogeneity, emulsions, multilayers), crystal type, shape, size, and lipid distribution (Morillon, et al., 2002).

Tongnuanchan et al. (2014) reported the tilapia gelatin film which was incorporated with basil, plai, and lemon essential oil and soy lecithin surfactant had a WVP value of $0.71 \pm 0.01 \times 10^{-11} \mathrm{~g} / \mathrm{msPa}, 1.01 \pm 0.01 \times 10^{-}$ ${ }^{11} \mathrm{~g} / \mathrm{msPa}$, and $0.75 \pm 0.04 \times 10^{-11} \mathrm{~g} / \mathrm{msPa}$ or decreased in WVP by $61.4 \%, 41.1 \%$ and $59.2 \%$ of the control film. Besides, Wu et al. (2017) also reported that films from silver carp skins that were incorporated with cinnamon essential oil and tween 80 surfactants had WVP values of $1.52 \pm 0.05 \times 10^{-10} \mathrm{~g} / \mathrm{msPa}$ or decreased by $61.70 \%$ of control films. Incorporation of essential oil could enhance the water vapor barrier property of gelatin film, in which the capability was dependent on the types of essential oils used (Tongnuanchan et al., 2014).

\subsection{Solubility}

The solubility of edible films can be a parameter of the water-resistance of the film (Rhim et al., 2000). Table 2 presents the solubility of edible films incorporated with two types of essential oils and surfactants. The highest solubility value in the edible film control, while the lowest value in the clove-soy lecithin edible film (CSF). Duncan's further test results on the solubility of the edible film showed that the addition of clove essential oil significantly affected $(\mathrm{P}<0.05)$ on the decrease of film solubility, but the addition of ginger essential oil and surfactant did not significantly affect the solubility of the edible film $(\mathrm{P}>0.05 \%)$. This is due to the interaction of the hydrophobic component of the clove essential oil with the hydrophobic component of gelatin thereby increasing the hydrophobicity of the edible film. This causes the solubility of edible films to decrease. A decrease in the solubility of edible gelatin films was also reported Ahmad et al. (2012), where the bergamot essential oil and lemongrass added as much as $25 \%(\mathrm{w} / \mathrm{w})$ filmforming solution can reduce the solubility of edible film. The greatest solubility in edible film control was $97.80 \%$, while the lowest was in an edible film with lemongrass was $89.16 \%$.

\subsection{FTIR spectra of edible film}

In this study the transmittance spectrum tested was from wavenumbers $400-4000 \mathrm{~cm}^{-1}$ which corresponds to the absorption of active functional groups of edible films. The vibrational mode that is often observed in infrared spectroscopy is a strain where the bond length changes when it vibrates and requires more energy.

The FTIR spectra of edible films are depicted in Figure 1. In the spectra image, it can be identified that in the range of wave numbers $3273-3306 \mathrm{~cm}^{-1}$ is the spectrum of amide A, while in wave number 2922-2933 $\mathrm{cm}^{-1}$ is the region of amide $\mathrm{B}$. Amide A represents the absorption of the NH stretching coupled with hydrogen bonds while the amide B corresponds with $\mathrm{CH}$ strain. While the spectra in the range of $1635-1651 \mathrm{~cm}^{-1}$ (amide I) is related to the vibrations of $\mathrm{C}=\mathrm{O}$ stretching/hydrogen bonding coupled with $\mathrm{COO}$. The addition of essential oils generally gives a higher amplitude to amide A amide 1 than control edible films. The addition of clove essential oil and soy lecithin showed the highest increase in amplitude. This indicates an interaction between eugenol compounds in clove essential oil and hydrophobic groups in gelatin which causes gelatin to experience cross-linking, thus increasing the hydrophobicity of edible films. Besides the increase in hydrophobicity of edible film was also shown in the solubility test, where the addition of clove essential oil 
significantly affected the edible film's solubility or increased hydrophobicity of edible film.

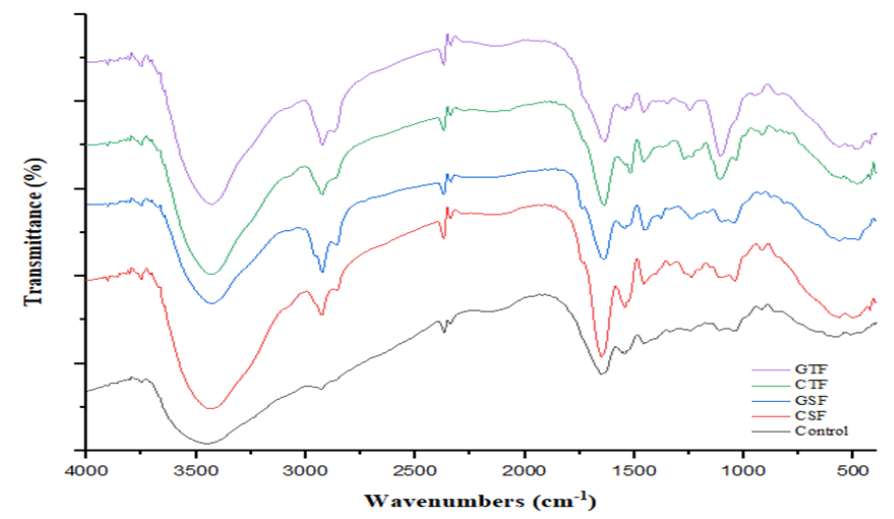

Figure 1. FTIR spectra of edible films. GTF $=$ ginger-Tween ${ }^{\circledR}$ 20 edible film; CTF $=$ clove-Tween ${ }^{\circledR} 20$ edible film; GSF $=$ ginger-soy lecithin edible film; CSF = clove-soy lecithin edible film; control $=$ control edible film

\subsection{Antioxidants activity}

Table 3 presents the antioxidant activity of edible films incorporated with two types of essential oils and surfactants. From Duncan's continued test results, edible film plus clove essential oil significantly affected $(\mathrm{P}<0.05)$ its antioxidant activity with an edible film. The edible film added with surfactant type (Tween ${ }^{\circledR} 20$, soy lecithin) significantly different antioxidant activity with edible film control and between edible film added with different surfactant types $(\mathrm{P}<0.05)$, where edible film added clove essential oil and Tween ${ }^{\circledR} 20$ (CTF) had the highest antioxidant activity of $52.22 \pm 14.81 \%$ with the DPPH free radical immersion method at a concentration of $50 \mathrm{ppm}$. Antioxidant activity is related to the main active component in essential oils. According to Radünz et al. (2019), the main component of clove essential oil is eugenol $(56.06 \%)$ followed by caryophyllene $(39.63 \%)$ and $\alpha$-caryophyllene $(4.31 \%)$, where this component has natural antioxidant potential. The antioxidant activity of clove essential oil was higher than BHT $>\alpha$ tocopherol>BHA>Trolox which was 83.6, 67.8, 64.9, 62.5 , and $29.4 \%$ at concentrations of $45 \mu \mathrm{g} / \mathrm{mL}$. While based on Bellik et al. (2013), the antioxidant activity of ginger essential oil was $19.92 \pm 2.80 \%$ to $68.31 \pm 3.32 \%$ with concentrations ranging from 1.2 to $19.17 \mathrm{mg} / \mathrm{mL}$. Based on this, it will affect the antioxidant activity of edible films, where clove edible films are higher than ginger or control edible films.

The addition of Tween ${ }^{\circledR} 20$ had a higher effect than soy lecithin on edible film, although statistically not significantly different. This is thought to be related to the film's emulsion system in the form of oil-in-water emulsions. The oil-in-water emulsion system is more stable when an emulsifier with a high HLB value is added. Tween ${ }^{\circledR} 20$ (HLB: 16.7) has a higher HLB than soy lecithin (HLB: 4). In the clove-Tween ${ }^{\circledR} 20$ film emulsion, the functional group of the essential oils is completely dispersed (forming droplets), giving a higher antioxidant effect. However, edible control films also showed antioxidant activity against DPPH free radicals of $3.07 \pm 2.60 \%$. This is due to the peptide fraction of gelatin containing amino acids such as glycine and proline which have antioxidant activity (Kim et al., 2001).

As a comparison material (positive control) BHT (butylated hydroxytoluene) antioxidant activity was also obtained $\mathrm{IC}_{50}$ value (effective concentration value that can inhibit $50 \%$ oxidation) of $9.06 \mathrm{ppm}$ while at a concentration of $50 \mathrm{ppm}$ the antioxidant activity value of CTF $52.22 \%$. It can be stated that the antioxidant activity of BHT is equivalent to 5.5 times the antioxidant activity of edible film added with clove essential oil and tween surfactant $20 . \mathrm{IC}_{50} \mathrm{BHT}$ is calculated by comparing the concentration of BHT with the value (\%) of antioxidant activity in a regression linear.

\subsection{Antibacterial activity}

Gelatin films incorporated with different essential oils and surfactants are tested against the selected bacteria (E. coli and S. aureus) to determine antibacterial activity (Table 3 ). Based on the results of the study, the

Table 3. Antioxidant activity and antibacterial edible film

\begin{tabular}{cccc}
\hline \multirow{2}{*}{ Sample } & Antioxidants & \multicolumn{2}{c}{ Antibacterial } \\
\cline { 2 - 4 } & $\begin{array}{c}\text { Radical Scavenging } \\
\text { Activity }(\%)\end{array}$ & $\begin{array}{c}\text { Inhibitory zone } \\
\text { E. coli }(\mathrm{mm})\end{array}$ & $\begin{array}{c}\text { Inhibitory zone } \\
\text { S. aureus }(\mathrm{mm})\end{array}$ \\
\hline Control & $3.07 \pm 2.60^{\mathrm{Aa}}$ & $0.00^{\mathrm{Aa}}(\mathrm{ND})$ & $0.00^{\mathrm{Aa}}(\mathrm{ND})$ \\
GTF & $5.55 \pm 1.40^{\mathrm{Ab}}$ & $5.87 \pm 0.70^{\mathrm{Bb}}$ & $3.97 \pm 0.28^{\mathrm{Bb}}$ \\
GSF & $4.61 \pm 1.04^{\mathrm{Aab}}$ & $6.84 \pm 0.28^{\mathrm{Bc}}$ & $4.84 \pm 1.16^{\mathrm{Bb}}$ \\
CTF & $52.22 \pm 14.81^{\mathrm{Bb}}$ & $12.85 \pm 1.05^{\mathrm{Cb}}$ & $19.33 \pm 4.01^{\mathrm{Cb}}$ \\
CSF & $19.91 \pm 4.87^{\mathrm{Bab}}$ & $8.93 \pm 0.74^{\mathrm{Cc}}$ & $14.97 \pm 2.34^{\mathrm{Cb}}$ \\
\hline
\end{tabular}

Values with different uppercase letter superscripts indicate significant difference $(\mathrm{p}<0.05)$ among essential oils while values with different lowercase letter superscripts indicate significant difference $(p<0.05)$ in the treatment of surfactants. GTF $=$ gingerTween ${ }^{\circledR} 20$ edible film; GSF = ginger-soy lecithin edible film; CTF = clove-Tween ${ }^{\circledR} 20$ edible film; CSF = clove-soy lecithin edible film. 
edible film added with ginger and clove essential oils can inhibit the growth of E. coli and S. aureus. Based on the results of Duncan's further tests on the antibacterial activity of edible films showed the addition of essential oils significantly $(\mathrm{P}<0.05)$ to increase the antibacterial activity of edible films both against $E$. coli and $S$. aureus. The addition of clove essential oil has the effect of inhibiting higher antimicrobial activity than the addition of ginger essential oil. This is because the MIC (minimum inhibitory concentration) value of clove essential oil is lower than ginger essential oil. Based on research by Lee et al. (2009), the MIC value of cloves was $0.015 \mu \mathrm{g} / \mathrm{mL}-0.062 \mu \mathrm{g} / \mathrm{mL}$ while the MIC value of ginger essential oils was 3.9-62.5 $\mu \mathrm{L} / \mathrm{mL}(3,900-62,500$ $\mu \mathrm{g} / \mathrm{mL}$ ) (Debbarma et al., 2012) .

Likewise, the addition of Tween ${ }^{\circledR} 20$ surfactants and soy lecithin had a significant effect $(\mathrm{P}<0.05)$ on the increased antibacterial activity of edible films. Tween ${ }^{\circledR}$ 20 exerts an increased effect on antibacterial activity than soy lecithin. This is related to the stabilization of the film emulsion system in the form of an oil-in-water emulsion. The oil-in-water emulsion system is more stable when an emulsifier with a high HLB value is added. Tween ${ }^{\circledR} 20$ (HLB: 16.7) has a higher HLB than soy lecithin (HLB: 4). In the clove-Tween ${ }^{\circledR} 20$ film emulsion, the functional group of the essential oil is completely dispersed (forming a droplet), giving a higher antibacterial effect. Uniformity of droplet shape (smaller diameter) of the emulsion film will increase the ability of penetration through bacterial cell wall membranes (Farshi et al., 2019).

Based on the results obtained clear zone areas are categorized into several categories, namely weak $(<=5$ $\mathrm{mm})$, moderate $(6-10 \mathrm{~mm})$, strong $(11-20 \mathrm{~mm})$, and very strong ( $>20 \mathrm{~mm}$ ) (Permadani, 2015). The highest antibacterial activity in $\mathrm{CTF}$ which can inhibit $E$. coli with a clear zone diameter of $12.85 \mathrm{~mm}$ and $S$. aureus of $19.33 \mathrm{~mm}$, and included in the category of strong antibacterial inhibition. The clear zone in $S$. aureus is higher than $E$. coli. This is because the two types of bacteria are different, where $S$. aureus bacteria are grampositive bacteria while $E$. coli bacteria are gram-negative bacteria. The cell wall structure of gram-negative bacteria is more complex compared to gram-positive bacteria, so that clove essential oil (eugenol) is easier to inhibit the growth of $S$. aureus bacteria compared to E.coli bacteria (Oliver et al., 2004). Lestari (2017) also reported that MID (minimum inhibitory dose) of clove essential oil in $S$. aureus bacteria was $25 \mu \mathrm{L} / \mathrm{L}$ while in E. coli bacteria was $50 \mu \mathrm{L} / \mathrm{L}$. The MID value needed by clove flower essential oil to inhibit the growth of $S$. aureus bacteria is smaller than E. coli. The lower MID value indicates stronger antibacterial activity, which means clove flower essential oil has greater antibacterial activity against gram-positive bacteria than gramnegative bacteria. The zone of inhibition by essential oils in fish gelatin edible films was also reported by $\mathrm{Wu}$ et al. (2017), were at a concentration of $2 \%$ cinnamon essential oil had given an inhibition zone of E. coli bacterial growth of $18.78 \mathrm{~mm}$ and $S$. aureus bacteria of $19.95 \mathrm{~mm}$.

When essential oils are added to edible films, essential oils are diffused into agar media and produce clear zones on microbial growth media. Factors affecting the size of the inhibitory area, namely the sensitivity of the organism, culture medium, incubation conditions, and the speed of agar diffusion (Utami et al., 2013).

The antibacterial ability of the clove essential oil obtained from the lipophilic nature of eugenol can cause bacterial cell membranes to undergo adhesion which causes inhibited bacterial respiration. This will disrupt transport in cells so that bacteria experience death. Besides, phenol groups contained in eugenol when attached to bacterial cells will make bacteria undergo lysis, then die (Kumala et al., 2008).

\section{Conclusion}

The addition of essential oils and surfactants has a significant effect on physical properties: thickness, color $* b$ edible film, but not significantly different in color values ${ }^{*} L$ and $* a$, no significant effect on elongation at break, however, the addition of clove essential oil increased the mechanical properties of the edible film (tensile strength), had no significant effect on WVP, and the addition of clove essential oil had a significant effect on the decrease in the solubility of the edible film of tuna skin gelatin. For the functional properties of tuna skin gelatin edible film, the addition of clove essential oil and surfactant increased the antioxidant activity of edible film, where the addition of clove essential oil and Tween ${ }^{\circledR} 20$ gives the highest increase in antioxidant activity on edible film. The antioxidant activity of edible film added with clove essential oil and Tween ${ }^{\circledR} 20$ surfactant (50 ppm concentration) is equivalent to the antioxidant activity of BHT at $5.5 \mathrm{ppm}$ concentration. The addition of essential oils (cloves and ginger) and surfactants (Tween ${ }^{\circledR} 20$ and soy lecithin) can inhibit the growth of $E$. coli and $S$. aureus. The highest antimicrobial activity in edible clove tween film 20 which can inhibit $E$. coli with a clear zone diameter of $12.85 \mathrm{~mm}$ and $S$. aureus of $19.33 \mathrm{~mm}$, and included in the category of strong antimicrobial inhibition. Therefore, tuna skin gelatin edible film incorporated with clove essential oil and surfactants could be used as an alternative active film packaging. 


\section{Acknowledgement}

The authors wish to thank to PPKI 2021 Grant for supporting this research.

\section{References}

Ahmad, M., Benjakul, S., Prodpran, T. and Agustini, T.W. (2012). Physico-mechanical and antimicrobial properties of gelatin film from the skin of unicorn leatherjacket incorporated with essential oils. Food Hydrocolloids, 28(1), 189-199. https:// doi.org/10.1016/j.foodhyd.2011.12.003

Anonim. (2020). Data produksi perikanan. Retrieved on 8 May 2020 from Statistik website: https:// statistik.kkp.go.id/home.phpm $=$ total\&i $=2 \#$ panelfooter. [In Bahasa Indonesia].

Atares, L. and Chiralt, A. (2016). Essential oils as additives in biodegradable films and coating for active food packaging. Trends in Food Science and Technology, 48, 51-62. https://doi.org/10.1016/ j.tifs.2015.12.001

Bellik, Y., Benabdesselam, F., Ayad, A., Dahmani, Z., Boukraa, L., Nemmar, A. and Iguer-Ouada, M. (2013). Antioxidant activity of the essential oil and oleoresin of Zingiber Officinale Roscoe as affected by chemical environment. International Journal of Food Properties, 16(6), 1304-1313. https:// doi.org/10.1080/10942912.2011.584257

Choi, I., Lee, S.E., Chang, Y., Lacroixc, M. and Han, J. (2018). Effect of oxidized phenolic compounds on cross-linking and properties of biodegradable active packaging film composed of turmeric and gelatin. LWT, 93, 427-43. https://doi.org/10.1016/ j.1wt.2018.03.065

Debbarma, J., Kishore, P., Nayak, B.B., Kannuchamy, N. and Gudipati, V. (2012). Antibacterial activity of ginger, eucalyptus and sweet orange peel essential oils on fish-borne bacteria. Journal of Food Processing and Preservation, 37(5), 1022-1030. https://doi.org/10.1111/j.1745-4549.2012.00753.x

Farshi, P., Tabibiazar, M., Ghorbani, M., Mohammadifard, M., Bannazadeh Amirkhize, M. and Hamishehkare, H. (2019). Whey protein isolateguar gum stabilized cumin seed oil nanoemulsion. Food Bioscience, 28, 49-56. https://doi.org/10.1016/ j.fbio.2019.01.011

Gómez-Guillén, M.C., Perez-Mateos, M., Gomez-Estaca, J., Lopez-Caballero, E., Gimenez, B. and Montero, P. (2009). Fish gelatin: a renewable material for developing active biodegradable films. Trends in Food Science and Technology, 20(1), 3-16. https:// doi.org/10.1016/j.tifs.2008.10.002

Hoque, M.S., Benjakul, S. and Prodpran, T. (2011).
Properties of film from cuttlefish (Sepia pharaonis) skin gelatin incorporated with cinnamon, clove and star anise extracts. Food Hydrocolloids, 25(5), 10851097. https://doi.org/10.1016/j.foodhyd.2010.10.005

Hosseini, S.F., Rezaei, M., Zandi, M. and Farahmand, F. (2013). Preparation and functional properties of fish gelatin-chitosan blend edible films. Food Chemistry, 136(3-4), 1490-1495. https://doi.org/10.1016/ j.foodchem.2012.09.081

Hsu, J.-P. and Nacu, A. (2003). Behavior of soybean oilin-water emulsion stabilized by nonionic surfactant. Journal of Colloid and Interface Science, 259(2), 374-381. https://doi.org/10.1016/S0021-9797(02) 00207-2

Kanmani, P. and Rhim, J.-W. (2014). Physical, mechanical and antimicrobial properties of gelatin based active nanocomposite films containing AgNPs and nanoclay. Food Hydrocolloids, 35, 644-652. https://doi.org/10.1016/j.foodhyd.2013.08.011

Kim, S.K., Kim, Y.T., Byun, H.G., Nam, K.S, Joo, D.S. and Shahidi. (2001). Isolation and characterization of antioxidative peptides from gelatin hydrolysate of Alaska pollack skin. Journal of Agricultural and Food Chemistry, 49(4), 1984-1989. https:// doi.org/10.1021/jf000494j

Kumala, Shirly and Dian Indriani. (2008). Efek antibakteri ekstrak etanol daun cengkeh (Eugenia aromaticum L). Jurnal Farmasi Indonesia, 4(2), 8286.

Lacroix, M. and Vu, K.D. (2014). Edible coating and film materials: Proteins. In Han, J.H. (Ed.) Innovations in food packaging, p. 277 - 294. San Diego, USA: Academic Press. https:// doi.org/10.1016/B978-0-12-394601-0.00011-4

Lee, S., Najiah, M., Wendy, W. and Nadirah, M. (2009). Chemical composition and antimicrobial activity of the essential oil of Syzygium aromaticum flower bud (Clove) against fish systemic bacteria isolated from aquaculture sites. Frontiers of Agricultural Science and Engineering, 3(3), 332-336. https:// doi.org/10.1007/s11703-009-0052-8

Lestari, W.C. (2017). Efek antibakteri uap minyak atsiri bunga cengkeh (Syzygium aromaticum L.) terhadap pertumbuhan Escherichia coli dan Staphylococcus aureus dengan metode gaseous contact. Yogyakarta, Indonesia: Universitas Islam Indonesia. BSc. Thesis. [In Bahasa Indonesia].

Makishi, G.L.A., Lacerda, R.S., Bittante, A.M.Q.B., Chambi, H.N.M., Costa, P.A. and Gomide, C.A. (2013). Films based on castor bean (Ricinus communis L.) proteins crosslinked with glutaraldehyde and glyoxal. Industrial Crops and 
Products, 50, 375-382. https://doi.org/10.1016/ j.indcrop.2013.07.025

Maryam Adilah, Z.A. and Nur Hanani, Z.A. (2016). Active packaging of fish gelatin films with Morinda citrifolia oil. Food Bioscience, 16, 66-71. https:// doi.org/10.1016/j.fbio.2016.10.002

McClements, D.J. (2005). Food emulsion principles, practices, and techniques. Boca Rota, Florida:

CRS Press. https://doi.org/10.1201/9781420039436

Morillon, V., Debeaufort, F., Blond, G., Capelle, M. and Voilley. (2002). Factors affecting moisture permeability of lipid-based edible films: A Review. Critical Reviews in Food Science and Nutrition, 42 (1), 67-89. doi.org/10.1080/10408690290825466

Newton, R., Telfer, T. and Little, D. (2014). Perspectives on the utilization of aquaculture coproduct in Europe and Asia: prospects for value addition and improved resource efficiency. Critical Reviews in Food Science and Nutrition, 54(4), 495-510. https:// doi.org/10.1080/10408398.2011.588349

Nisaa, A.A. (2020). Karakteristik fisikokimia, aktivitas antioksidan dan antimikrobia edible film gelatin kulit ikan nila (Oreochromis niloticus) yang diinkorporasi dengan minyak atsiri kayu manis dan serai. Yogyakarta, Indonesia: Universitas Gadjah Mada. BSc. Thesis. [In Bahasa Indonesia].

Nor Amalini, A., Norziah, M.H., Khan, I. dan Hafiz, M.K.M. (2018). Exploring the properties of modified fish gelatin films incorporated with different fatty acid sucrose esters. Food Packaging and Shelf Life, 15, 105-112. https://doi.org/10.1016/ j.fpsl.2017.12.003

Nur Hanani, Z.A., Yee, F.C. and Nor-Khaizura, M.A.R. (2019). Effect of pomegranate (Punica granatum L.) peel powder on the antioxidant and antimicrobial properties of fish gelatin films as active packaging. Food Hydrocolloids, 89, 253-259. https:// doi.org/10.1016/j.foodhyd.2018.10.007

Nurindra, A.P., Alamsjah, M.A. and Sudarno. (2015). Karakterisasi edible film dari pati propagul mangrove lindur (Bruguiera gymnorrhiza) dengan penambahan carboxymethyl cellulose $(\mathrm{cmc})$ sebagai pemLastis. Jurnal Ilmiah Perikanan dan Kelautan, 7 (2), 125-132. [In Bahasa Indonesia]. https:// doi.org/10.20473/jipk.v7i2.11195

Oliver, S.P., Gillespie, B.E., Almeida, R.A., Headrick, S.J., Dowlen, H.H., Johnson, D.L., Lamar, K.C., Chester, S.T. and Moseley, W.M. (2004). Extended centifur therapy for treatment of experimrntallyinduced Streptoccus uberis mastitis in lacting dairy cattle. Journal of Dairy Science, 87(2), 80-90.
https://doi.org/10.3168/jds.S0022-0302(04)73468-2

Permadani, I. (2015). Daya hambat ekstrak daun beluntas (Pluchea indica L.) Menggunakan pelarut etanol terhadap pertumbuhan bakteri Staphylococcus aureus dan Escherichia coli penyebab mastitis. Manado, Indonesia: Universitas Sam Ratulangi. MSc. Thesis. [In Bahasa Indonesia].

Pranoto, Y. (2008). Pembuatan Edible Film dari Gelatin Hasil Ekstraksi Kulit Ikan Nila (Oreochromis niloticus) dan Kerisi Putih (Pristipomoides multidens) dengan Penambahan k-Karaginan presented at the Seminar Nasional and Kongrress PATPI 2005, 14-16 Oktober 2008. Palembang, Indonesia. [In Bahasa Indonesia].

Pranoto, Y., Salokhe, V.M. and Rakshit, S.K. (2005). Physical and antibacterial properties of alginatebased edible film incorporated with garlic oil. Food Research international, 38(3), 267-272. https:// doi.org/10.1016/j.foodres.2004.04.009

Radünz, M., Martins da Trindadeb, M.L., Camargoa, T.M., Radünz, A.L., Borgesd, C.D., Gandrad, E.A. and Helbig, E. (2019). Antimicrobial and antioxidant activity of unencapsulated and encapsulated clove (Syzygium aromaticum, L.) essential oil. Food Chemistry, 276, 180-186. https://doi.org/10.1016/ j.foodchem.2018.09.173

Rukmana, R. and Yudirachman, H. (2016). Untung selangit dari agribisnis cengkeh, Yogyakarta, Indonesia: Lily Publisher. [In Bahasa Indonesia].

Sharma, P.K., Singh, V. and Ali, M. (2016). Chemical composition and antimicrobial activity of fresh rhizome essential oil of Zingiber officinale roscoe. Pharmacognosy Journal, 8, 185-189. https:// doi.org/10.5530/pj.2016.3.3

Sutono, D. and Pranoto, Y. (2013). Ekstrak rumput laut (Kappaphycus alvarezii) sebagai cross linking agent pada pembentukan edible film gelatin kulit ikan nila hitam (Oreochromis mosammbicus). AGRITECH, $33,168-175$.

Tkaczewska, J., Morawska, M., Kulawik, P. and Zajac, M. (2018).Characterization of carp (Cyprinus carpio) skin gelatin extracted using different pretreatments method. Food Hydrocolloids, 81, 169179. https://doi.org/10.1016/j.foodhyd.2018.02.048

Tongnuanchan, P., Benjakul, S. and Prodpran, T. (2014). Comparative studies on properties and antioxidative activity of fish skin gelatin films incorporated with essential oils from various sources. International Aquatic Research, 6(2), 1-12. https:// doi.org/10.1007/s40071-014-0062-x

Tongnuanchan, P., Benjakul, S. and Prodpran, T. (2012). Properties and antioxidant activity of fish skin 
gelatin film incorporated with citrus essential oils.

Food Chemistry, 134(3), 1571-1579. https://

doi.org/10.1016/j.foodchem.2012.03.094

Tongnuanchan, P., Benjakul, S. and Prodpran, T. (2013).

Physico-chemical properties, morphology and antioxidant activity of film from fish skin gelatin incorporated with root essential oils. Journal of Food Engineering, 117(3), 350-360. https:// doi.org/10.1016/j.jfoodeng.2013.03.005

Utami, R., Nurhartadi, E. and Putra, A.Y.T. (2013). Pengaruh penambahan minyak atsiri kunyit putih (Kaempteria rotunda) pada edible film pati tapioka terhadap aktivitas antimikroba dan sensoris. Jurnal Teknosains Pangan, 2, 51-56. [In Bahasa Indonesia].

Wu, J., Sun, X., Guo, X., Ge, S. and Zhang, Q. (2017). Physicochemical properties, antimicrobial activity and oil release of fish gelatin films incorporated with cinnamon essential oil. Aquaculture and Fisheries, 2 (4), 185-192. https://doi.org/10.1016/ j.aaf.2017.06.004

Yeh, H.Y., Chuang, C.H., Chen, H.C., Wan, C.J., Chen, T.L. and Lin, L.Y. (2014). Bioactive components analysis of two various gingers (Zingiber officinale roscoe) Andantioxidant effect of ginger extracts. LWT-Food Science and Technology, 55(1), 329-334. https://doi.org/10.1016/j.lwt.2013.08.003 